\title{
Peningkatan Keterampilan Membaca Puisi Menggunakan Media Power Point Interaktif pada Siswa SD Kelas II SDN 1 Teras Kec. Teras Kab. Boyolali Tahun Ajaran 2020/2021
}

\author{
Aerla Ayustata Dias \\ Universitas Sebelas Maret \\ aerla.tata@gmail.com
}

\section{Article History}

received 30/4/2021

\begin{abstract}
This research based of problems in the field that the results of the poetry reading skills of second grade students were less than the KKM. This research aims to determine the improvement of Indonesian poetry reading skills using Interactive Power Point learning media for second grade students. The research method used is Classroom Action Research (CAR) which is carried out in two cycles. The results of the research obtained indicate that the interactive Power Point media can improve the results of poetry reading skills. This is evidenced by an increase in the first cycle of $53.86 \%$. In the second cycle there was an increase of $23.07 \%$ with the acquisition of classical poetry reading skills, namely $92.31 \%$. This shows that students who have completed the KKM classically have $85 \%$.
\end{abstract}

Keywords: Poetry Reading Skills, Indonesian Language, Interactive Power Point Learning Media.

\section{Abstrak}

Penelitian ini diangkat adanya permasalahan di lapangan bahwa hasil keterampilan membaca puisi siswa kelas II kurang dari KKM. Penelitian bertujuan untuk mengetahui peningkatan keterampilan membaca puisi Bahasa Indonesia menggunakan media pembelajran Power Point Interaktif pada siswa kelas II. Metode penelitian yang digunakan adalah Penelitian Tindakan Kelas (PTK) yang dilaksanakan dengan dua siklus. Hasil dari penelitian yang didapatkan menunjukkan bahwa media Power Point Interaktif dapat meningkatkan hasil keterampilan membaca puisi. Hal ini dibuktikan dengan adanya peningkatan pada siklus I sebesar 53,86\%. Pada siklus II terjadi peningkatan sebesar $23,07 \%$ dengan peroleha hasil keterampilan membaca pusisi secara klasikal yaitu $92,31 \%$. Hal ini menunjukkan bahwa siswa yang tuntas KKM secara klasikal sudah $\geq 85 \%$.

Kata kunci: Keterampilan Membaca Puisi,Bahasa Indonesia, Media Pembelajaran Power Point Interaktif. 


\section{PENDAHULUAN}

Pembelajaran sesungguhnya sama dengan pengajaran, sehingga pengertian atau konsep-konsep dalam pengajaran dapat digunakan untuk menjelaskan pembelajaran. Pengarjaran merupakan suatu rangkaian kegiatan yang bertujuan untuk menciptakan suasana menyenangkan bagi peserta didik dan mewujudkan pencapaian hasil belajar yang tinggi. Pembelajaran dapat pula diaktakan sebagai sebuah proses yang bertujuan untuk mewujudkan pencapaiaan hasil belajar yang tinggi (Rasimin, 2012 : 47-48).

Dewasa ini pembelajaran yang sedang berjalan menghambat adanya keterampilan membaca puisi peserta didik. Pasalnya pembelajaran yang sedang berlangsung terkendala oleh adanya virus yang sedang menjadi centre dari permasalahan yang ada. Virus Covid-19 adalah sebuah virus yang mematikan dimana virus tersebut menghambat semua aktifitas yang ada di sekitar. Virus ini juga berdampak pada kegiatan belajar mengajar di skeolah-sekolah. Dampak pada pendidikan sangatlah besar, hal ini terlihat dalam kegiatan belajar mengajar siswa dan guru disuguhkan hal yang baru, yaitu belajar di rumah terbimbing dengan gurunya yang biasa disebut dengan pembelajaran daring. Berita Republika (Jum'at, 28 Agustus 2020)

Pembelajaran daring identik dengan pengintegrasian teknologi berupa aplikasiaplikasi pendukung pembelajaran dan juga melibatkan jaringan internet. Guru dan siswa diwajibkan melakukan pembelajaran secara daring yaitu siswa mendapatkan materi dari rumah sedangkan guru menyampaikan materi dengan menggunakan media aplikasi berbasis teknologi yang ada di rumah. Dalam kondisi yang seperti ini, tujuan pembelajaran tetaplah harus tercapai secara maksimal. Pada revolusi industri 4.0 ini banyak sekali aplikasi dan teknologi yang bermunculan yang bisa dimanfaatkan untuk melakukan pembelajaran secara daring. Sayangnya tidak sedikit pula sekolah-sekolah yang tidak bisa mencapai tujuan pembelajaran karena terkendala. Ali Sadikin: Jurnal Ilmiah Tahun 2020.

Menurut Rahmanto (1988: 49) dalam jurnal Wulandari Puisi adalah sebuah karya sastra yang merupakan sebuah karya seorang penyair didalamnya berisikan kata-kata indah atau puitis berupa pesan dan kesan terhadapat objek yang dibawakan akan menyentuh gerak hati seseorang yang mendengarkannya.

Membaca puisi adalah salah satu tujuan pembelajaran yang harus tercapai meskipun keadaan tidak mendukung, jika hal ini terus dibiarkan maka pada materimateri pusii di kela sberikutnya siswa akan terkendala di sisi lain juga siswa akan merasakan kesulitan dalam mengapresiasikan karya sastra puisi. Tetapi pada praktiknya ternyata banyak sekali kendala yang terdapat pada lapangan yang berdampak pada tercapainya tujuan pembelajaran secara daring. Beberapa hal yang menjadi kendala dalam tercapainya tujuan pembelajaran membaca puisi yaitu seperti sarana prasarana kurang memadai, serta pengetahuan guru yang hanya mengetahui beberapa aplikasi sehingga tidak bisa melakukan pembelajaran secara utuh dan komprehensif.

Berdasarkan survey yang dilakukan oleh peneliti di SD Negeri 1 Teras Kecamatan Teras Kabupaten Boyolali pada tanggal 21 November 2020 ditemukan beberapa kendala dalam mencapai tujuan pembalajaran yaitu membaca puisi yang memberikan dampak pengetahuan yang didapatkan oleh siswa tidak maksimal dan secara otomatis dalam mengembangkan keterampilan membaca puisi juga terbatas karena dalam penyerapan materi puisi kurang maksimal. Hal ini ditunjukkan dengan data dari jumlah siswa kelas II sebanyak 13 siswa hanya 5 siswa dengan prosentase $38,46 \%$ yang memenuhi standar Kriteria Ketuntasan Minimal dalam keterampilan membaca puisi yang ditetapkan oleh sekolah yaitu 70 dan 8 siswa dengan prosentase $61,53 \%$ mendapatkan nilai dibawah 70 . Hal ini menunjukkan bahwa pencapaian nilai KKM secara klasikal belum mencapai 85\%. (Trianto 2010:241) 
Berdasarkan hasil wawancara peneliti dengan guru kelas II SD Negeri 1 Teras Kecamatan Teras Kabupaten Boyolali didapatkan faktor yang mempengaruhi pencapaian nilai KKM secara klasikal dalam membaca puisi belum mencapai $85 \%$. Faktor tersebut diantaranya adalah kurangnya pemahaman guru terhadap teknologi yang ada dimana guru hanya mengetahui 1 aplikasi untuk menyampaikan materi membaca puisi yang berdampak pada kurangnya keterampilan siswa dalam membaca puisi dengan lafal, intonasi, ekspresi dan gaya dengan tepat yang disampaikan guru karena guru hanya memberikan materi dan memberikan tugas melalui aplikasi WhatsApp Group tidak ada media lain yang mendukung pembelajaran, sehingga pembelajaran yang berlangsung tidak tersampaikan secara maksimal dan juga pembelajaran yang berlangsung cenderung monton sehingga tidak timbulnya ketertarikan siswa dalam mempelajari materi yang ada.

Berdasarkan permasalahan yang ada di atas, guru hendaknya mampu menjadikan diri sebagai pribadi yang melek teknologi dan mengikuti perkembangan zaman serta mampu mengembangkan kreatifitas juga inovasi dalam penentuan media pembelajaran sehingga mampu menciptakan pembelajaran yang efektif, kondusif, menyenangkan, lebih bermakna dan juga siswa menjadi lebih aktif ketika pembelajaran berlangsung meskipun secara daring.

Media Power Point Interaktif adalah sebuah media yang menurut peneliti mampu meningkatkan keterampilan membaca puisi bagi siswa. Adapun wujud dari media power point interaktif adalah sebuah software yang pada aplikasi di dalam PC lebih spesifik adalah software microsoft office dimana di dalamnya terdapat sebuah pointpoint dalam mebaca puisi. Di dalam point-point tersebut terdapat sebuah contoh membaca puisi secara terbimbing dimana di dalam power point di desain semenarik mungkin yang berisi video dan juga gambar-gambar menarik yang sesuai dengan karakterisik atau gaya belajar siswa kelas II yang menyukai gambar-gambar bewarna. Hal ini dapat dimanfaatkan oleh guru untuk dijadikan sebagai dasar dalam mengembangkan media power point tersebut. Dengan adanya point terbimbing pada power point interaktif maka siswa dapat mengimplementasikan lafal, intonasi dan juga ekspresi yang tepat dalam membaca puisi.

Media Power Point Interaktif terbukti dapat meningkatkan keterampilan berbicara, hal ini dibuktikan dengan adanya penelitian terdahulu yang dilakukan oleh Mifathul Wahidah tahun 2017 dengan judul Penerapan Media Power Point Interaktif untuk Meningkatkan Keterampilan Berbicara Siswa Kelas I SDN Genukwatu IV Ngoro Jombang yang dilakukan dengan 2 siklus. Peningkatan hasil pengamatan pada prasiklus rata-rata 19,14, sedangkan pada siklus I mengalami peningkatan yaitu 36, sedangkan pada siklus II mengalami peningkatan 51,6. Sedangkan bukti secara kuntitatif siswa mengalami peningkatan rata-rata, yaitu pada pra-siklus nilai rata-rata 51,1 , siklus I adalah 61,9, dan siklus II adalah 80,9.

Berdasarkan uraian tersebut peneliti menawarkan solusi kepada guru untuk menyelesaikan masalah yang ada bersama guru dengan melakukan penelitian tindakan kelas dengan judul "Peningkatan Keterampilan Membaca Puisi Melalui Penggunaan Media Power Point Interaktif pada Siswa Kelas II Semester 2 SDN 1 Teras Kecamatan Teras Kabupaten Boyolali Tahun Pelajaran 2020/2021".

\section{METODE}

Metode yang digunakan pada penelitian ini adalah Penelitian Tindakan Kelas (PTK) model Kemmis \& Mc Taggart (dalam Arikunto, 2013:138-140) yang dilaksanakan dalam 2 siklus yaitu siklus I dan siklus II yang masing dilakukan dalam setiap siklus terdiri dari perencanaan, tindakan dan observasi serta refleksi (Suharsimi; 2007:107). Pelaksanaan penelitian ini dilaksanakan pada siswa kelas II SDN 1 Teras yang berjumlah 13 siswa dengan 9 siswa laki-laki dan 4 siswa perempuan. 
Data hasil penelitian berupa data kuantitatif dan kulaititatif yang bersumber pada perolehan nilai keterampilan membaca puisi peserta didik dan penjelasan dari data yang didapatkan. Adapun teknik pengumpulan datanya adalah dengan menggunakan test yang memiliki instrument penilaian lafal, ekspresi, intonasi dan gaya, kemudian ada teknik observasi, wawancara dan studi dokumentasi.

Indicator keberhasilan penelitian yaitu kriteria ketuntasan minimal keterampilan membaca puisi mencapai 70 dan secara klasikal mencapai $\geq 85 \%$ (Trianto: 2010:241).

\section{HASIL DAN PEMBAHASAN}

Penelitian Tindakan Kelas ini dilakukan melalui 2 siklus yaitu siklus I dan siklus II yang mengacu pada model Kemmis \& Mc Taggart ada beberapa tahapan dalam penelitian ini, yaitu: (1) perencanaan, (2) pelaksanaan, (3) pengamatan, (4) refleksi yang dilakukan pada siswa kelas II SDN 1 Teras.

Penelitian ini mengaplikasikan media pembelajaran Power Point Interaktif untuk menunjang pembelajaran di kelas sehingga hasil keterampilan siswa dalam membaca puisi menjadi lebih optimal dan mencapai nilai ketuntasan 70 dan ketuntasan secara klasikal mencapai $\geq 85 \%$.

Dari hasil penerapan media Power Point Interaktif dalam pembelajaran si kelas maka didapatka hasil data pada siklus I dan siklus II adalah sebagai berikut :

Tabel 1. Hasil Keterampilan Membaca Siswa Siklus I

\begin{tabular}{lccc}
\hline \multicolumn{1}{c}{ Aspek } & Pra Siklus & Siklus I & Siklus II \\
\hline Nilai Rata-rata & 59.61 & 72.38 & 81.38 \\
Siswa yang Tuntas & 2 & 9 & 12 \\
Siswa yang belum Tuntas & 11 & 4 & 1 \\
Prosentase siswa Tuntas & $15.38 \%$ & $69.24 \%$ & $92.31 \%$ \\
Prosentase siswa belum & $84.68 \%$ & $30.76 \%$ & $7.69 \%$ \\
Tuntas & & \\
\hline
\end{tabular}

Dari table di atas dapat dilihat bahwa pada pra siklus masih banyak siswa yang belum memenuhi batas KKM mata pelajaran Bahasa Indonesia yaitu 70 dan prosentasi ketuntasan secara klasikal belum mencapai $85 \%$. Dari data yang diperoleh siswa yang telah mencapai KKM sebanyak 15,38 \% (2 siswa) dan 84,62\% (11 siswa) belum mencapai KKM. Berdasarkan hal ini peneliti mencoba untuk melakukan tindakan perbaikan menggunakan media pembelajaran Power Point Interaktif untuk meningkatkan keterampilan membaca puisi pada siswa kelas II.

Pada siklus I media pembelajaran Power Point Interaktif sudah di terapkan dan bisa dilihat bahwa terjadi peningkatan nilai keterampilan membaca puisi pada siswa kelas II. Nilai rata-rata siswa menunjukkan bahwa hasil keterampilan membaca puisi siswa cukup memuaskan karena sebanyak 69.23\% (9 siswa) sudah mencapai nilai KKM keterampilan membaca puisi dan sebanyak $30.76 \%$ (4 siswa) belum mencapai KKM dengan rata-rata yang diperoleh 72.38. Tetapi ternayta indicator kerja atau ketuntasan secara klasikal belum mencapai $85 \%$ sehingga penelitian harus dilanjutkan ke siklus berikutnya.

Pada siklus II berdasarkan refleksi pada siklus I ternyata kriteria ketuntasan minimal secara klasikal belum terpenuhi $85 \%$, oleh sebab itu maka penelitian dilanjutkan dengan tetap menggunakan media pembalajaran Power Point Interaktif tetapi dnegan ditunjang dengan metode atau aspek yang lain. Data yang dihasilkan adalah hasil keterampilan membaca puisi siswa pada silus II mengalami peningkatan dan perkembangan dibandingkan pada siklus I. Pencapaian rata-rata pada siklus I mencapai 72,38 dan pada siklus II meningkat menjadi 81,38. Pada pelaksanan siklus II siswa yang telah mencapai KKM sebanyak 92,31\% (12 siswa) dan 7,69\% (1 siswa) 
belum mencapai KKM. Pada siklus II masih ada siswa yang belum mencapai KKM tetapi dari data yang didapatkan sudah menunjukkan peningkatan dan sudah menunjukkan hasil yang termasuk sangat memuaskan, karena sudah mencapai indikator keberhasilan klasikal yang telah ditetapkan yaitu ketuntasan belajar siswa minimal $85 \%$.

Di bawah ini disajikan sebuah diagram peningkatan hasil keterampilan membaca puisi siswa kelas II dari pra siklus, siklus I dan siklus II yang lebih jelas :

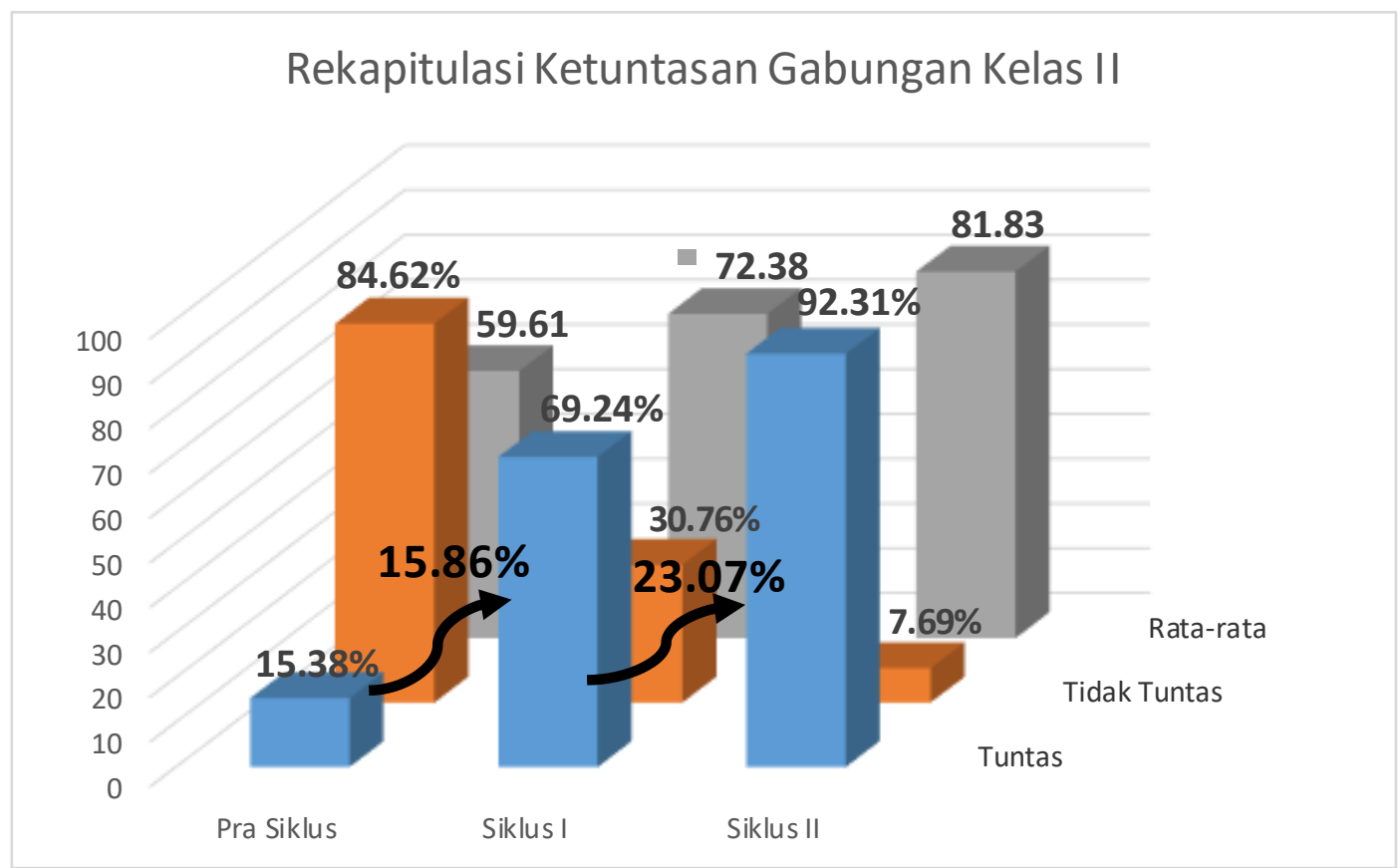

Gambar 1. Rekapitulasi Ketuntasan Gabungan Kelas II

Berdasarkan data tersebut maka dapat diketahui bahwa pelaksanaan PTK dnegan menggunakan media pembelajaran Power Point Interaktif berhasil meningkatkan hasil belajar siswa pada mata pelajaran Bahasa Indonesia dalam materi membaca puisi. Penerapan media pembelajaran Power Point Interaktif tampak memberikan perubahan yang positif dalam kegiatan belajar mengajar. Dampak positif tersebut terlihat dari peserta didik yang aktif, semangat, dan focus dalam mengikuti kegiatan belajar mengajar. Hal tersebut sejalan dengan penelitian yang dilakukan oleh Miftahul Wahidah tahun 2017 yaitu media pembelajaran Power Point Interaktif terbukti dapat meningkatkan keterampilan berbicara siswa kelas I.

Berdasarkan data tersebut dapat diketahui bahwa media pembelajaran Power Point Interaktif terbukti dapat meningkatkan hasil keterampilan membaca puisi siswa di kelas II SD Negeri 1 Teras Kecamatan Teras Kabupaten Teras Tahun Pelajaran 2020/2021.

\section{SIMPULAN}

Berdasarkan hasil penelitian tindakan kelas yang dilakukan di SD Negeri 1 Teras Kec. Teras Kab. Boyolali Tahun Pelajaran 2020/2021, dapat disimpulkan bahwa penerapan media pembelajaran Power Point Interaktif dapat meningkatkan hasil keterampilan mata pelajaran Bahasa Indonesia dalam materi Membaca Puisi pada siswa kelas II semester 2 SD Negeri 1 Teras. Hal ini dibuktikan dengan adanya peningkatan hasil keterampilan membaca puisi siswa pada setiap siklusnya yaitu terjadi peningkatan prosentase ketuntasan siswa sebesar $53,86 \%$ hal ini dapat dilihat pada kondisi pra siklus (awal) dari 13 siswa hanya 2 siswa $(15,38 \%$ ) siswa yang 
memenuhi standar kriteria ketuntasan minimal dan 11 siswa $(84,62 \%)$ belum memnuhi standar kriteria ketuntasan minimal dengan perolehan nilai rata-rata 59,61, sedangkan data yang didapat pada siklus 1 yaitu dari 13 siswa sebanyak 9 siswa $(69,24 \%)$ sudah memenuhi standar kriteria ketuntasan minimal dan 4 siswa $(30,76 \%)$ belum memenuhi standar kriteria ketuntasan minimal dengan perolehan nilai rata-rata 72,38 . Terjadi peningkatan prosentase ketuntasan dari siklus 1 ke siklus 2 sebesar $23,07 \%$. Hal ini dapat dilihat dari hasil belajar siswa yaitu dari 13 siswa sebanyak 12 siswa $(92,31 \%)$ sudah memenuhi standar kriteria ketuntasan minimal dan 1 siswa $(7,69 \%)$ belum memenuhi standar kriteria ketuntasan minimal dengan perolehan nilairata-rata 81,38.

Maka dapat dikatakan bahwa Penelitian Tindakan Kelas ini dinyatakan berhasil karena indikator keberhasilan secara klasikal yaitu $\geq 85 \%$ sudah tercapai hal ini dibuktikan dengan adanya data hasil belajar siswa pada siklus 2 sebesar $92,31 \%$ dengan perolehan nilai rata-rata $81,38(92,317 \% \geq 85 \%)$. Maka siklus dihentikan atau dinyatakan berhenti pada siklus 2 karena Indikator Keberhasilan secara klasikal dan individual sudah terpenuhi atau tercapai.

\section{DAFTAR PUSTAKA}

Ali Sadikin: Jurnal Ilmiah Tahun 2020. Pembelajaran Daring di Tengah Wabah Covid19. Jurnal Ilmiah Pendidikan Biologi. Vol. 06 No.02.

Arikunto, dkk. 2007. Penelitian Tindakan Kelas. Jakarta : PT. Bumi Askara

Choirunissa, Elfa. 2019. Efektivitas Penggunaa Media Presentasi (Power Point) Terhadap Keterampilan Menulis Puisi Siswa Kelas $V$ di SDN Blimbing 1 Kecamatan Kosambi Tangerang. Jakarta: Program Studi Pendidikan Guru Madrasah Ibtidaiyah Fakultas IImu Tarbiyah dan Keguruan Universitas Islam Negeri Syarif Hidayatullah.

Hanif, Sajida dkk. 2018. Peningkatan Keterampilan Membaca Puisi dengan Eksprementasi Model CIRC Bermedia Video Pembacaan Puisi Pada Siswa Kelas V SD 1 Tritis Jepara. Jurnal Kredo. Vol. 2 No. 1. 2598-3202.

Juwairiah. 2013. Alat Peraga dan Media Pembelajaran Kimia. Jurnal IImu Pendidikan, (Online), Vol. IV, No. 1, (diakses 8 Desember 2018 pukul 07.04 WIB).

Kunandar. 2011. Langkah Mudah Penelitian Tindakan Kelas Sebagai Pengembangan Profesi Guru. Jakarta : Rajawali Pers

Ningsih dan Reski. 2014. Media Pmebelajaran Berbasis Power Point. http://rhayanti.blogspot.com/2014/10/media-pembelajaran-berbasis-powerpoint.html (diakses Selasa, 15 Desember 2020)

Rasimin. 2012. Pembelajaran IPS Teori, Aplikasi dan Evaluasi. Salatiga : STAIN Salatiga Pers.

Ruang $2020 . \quad$ Guru. Pengertian Media Pembelajaran. https://ruangguruku.com/pengertian-media-pembelajaran/ (diakses Selasa, 15 Desember 2020, pukul 10:03 WIB).

Sulkifli dan Marwati. 2016. Kemampuan Menulis Puisi Slswa Kelas VIII SMP Negeri Satu Atap 3 Langgikima Kabupaten Konawe Utara. Jurnal Bastra Vol. 1 No. 1. 2503-3875.

Susanti, Rini Dwi. 2015. Pembelajaran Apresiasi Sastra di Sekolah Dasar. Jurnal Pendidikan. Vol. 3 No.1.

Trianto. 2010. Mendesain Model Pembelajaran Inovatif-Progresif: Implementasinya pada Kurikulum Tingkat Satuan Pendidikan(KTSP). Jakarta : Rencana Prenada Media Group.

Wahidah, Miftahul. 2017. Penerapan Media Power Point Interaktif untuk Meningkatkan Keterampilan Berbicara Siswa Kelas I SDN Genukwati IV Ngoro Jombang. Malang: Jurusan Pendidikan Guru Madrasah Ibtidaiyah Fakultas IImu Tarbiyah dan Keguruan Universitas Islam Negeri Maulana Malik Ibrahim Malang. 